\title{
JOB INSECURITY, LINGKUNGAN KERJA, KEPUASAN KERJA DAN KOMITMEN ORGANISASI PENGARUHNYA TERHADAP TURNOVER INTENTION KARYAWAN
}

\author{
Rina Irawati \\ STIE Malangkucecwara \\ Malang \\ e-mail : rina.ira@stie-mce.ac.id
}

\begin{abstract}
The purpose of this study is to examine the effect of job insecurity, job satisfaction, work environment and organizational commitment on employee turnover intention simultaneously and partially. The sample used in this study amounted to 55 employees of Java Dancer Coffee Malang. Validity and reliability test results show that each item from each variable is said to be valid and reliable. The results of the classic assumption test show that all variables are free from multicollinearity, heteroscedasticity and normal distribution. The results of the $F$ test indicate that there is a simultaneous influence between Job Insecurity (X1), Job Satisfaction (X2), Work Environment (X3), Organizational Commitment (X4) to Turnover Intention (Y) employees. The t-test results show that Job Satisfaction (X2), Work Environment (X3) and Organizational Commitment (X4) have a positive and significant effect on Turnover Intention (Y) employees of Java Dancer Coffee Malang, while Job Insecurity (X1) has no influence significant to Turnover Intention $(Y)$ variables. employee of Java Dancer Coffee Malang. The most influential variable Organizational Commitment to Turnover Intention compared to other variables. This can be known based on the calculation of the regression coefficient (b) of 0.522.
\end{abstract}

\begin{abstract}
ABSTRAK
Tujuan dari penelitian ini adalah untuk menguji pengaruh ketidakamanan kerja, kepuasan kerja, lingkungan kerja dan komitmen organisasi terhadap intensi turnover karyawan secara simultan dan parsial. Sampel yang digunakan dalam penelitian ini berjumlah 55 karyawan Java Dancer Coffee Malang. Hasil uji validitas dan reliabilitas menunjukkan bahwa setiap item dari masing-masing variabel dikatakan valid dan reliabel. Hasil uji asumsi klasik menunjukkan bahwa semua variabel bebas dari multikolinearitas, heteroskedastisitas dan berdistribusi normal. Hasil uji $\mathrm{F}$ menunjukkan bahwa terdapat pengaruh secara simultan antara Job Insecurity (X1), Job Satisfaction (X2), Work Environment (X3), Organizational Commitment (X4) terhadap Turnover Intention (Y) karyawan. Hasil uji t menunjukkan bahwa Kepuasan Kerja (X2), Lingkungan Kerja (X3) dan Komitmen Organisasi (X4) berpengaruh positif dan signifikan terhadap Turnover Intention (Y) karyawan Java Dancer Coffee Malang, sedangkan Job Insecurity (X1) berpengaruh positif dan signifikan terhadap Turnover Intention (Y) karyawan Java Dancer Coffee Malang, sedangkan Job Insecurity (X1) memiliki pengaruh positif dan signifikan terhadap Turnover Intention (Y). tidak ada pengaruh yang signifikan terhadap variabel Turnover Intention (Y). karyawan Java Dancer Coffee Malang. Variabel Organizational Commitment to Turnover Intention paling berpengaruh dibandingkan variabel lainnya. Hal tersebut dapat diketahui berdasarkan perhitungan koefisien regresi (b) sebesar 0,522.
\end{abstract}




\section{Buletin Ekonomi}

Kata Kunci : Job Insecurity, Lingkungan Kerja, Kepuasan Kerja, Komitmen Organisasi, Turnover Intention.

\section{PENDAHULUAN}

Kompetisi antar perusahaan di era global saat ini semakin ketat karena perusahaan tidak hanya dihadapkan pada persaingan dalam negeri, tetapi juga luar negeri. Oleh karenanya dibutuhkan strategi dan kebijakan manajemen untuk menghadapi hal tersebut, khususnya dalam penanganan sumber daya manusia. Organisasi harus melakukan langkahlangkah manajerial yang tepat dalam merekrut, menyeleksi, dan mempertahankan sumber daya manusia.

Pergantian karyawan (turnover intention) dalam organisasi merupakan fenomena penting. Ada kalanya pergantian karyawan memiliki dampak positif, namun sebagian besar membawa pengaruh yang kurang baik terhadap organisasi, baik dari segi biaya maupun dari segi hilangnya waktu dan kesempatan untuk memanfaatkan peluang (Pane, 2013). Tingkat perpindahan karyawan yang tinggi akan menimbulkan dampak negatif seperti timbulnya ketidakstabilan pada beberapa sektor pekerjaan yang ditinggalkan oleh karyawan serta peningkatan biaya sumber daya manusia yakni berupa biaya rekrutmen sampai pelatihan karyawan (Fadzilah, 2016). Tingkat perpindahan karyawan juga akan mengakibatkan organisasi tidak efektif karena perusahaan kehilangan karyawan berpengalaman dan perlu melatih kembali karyawan baru, sehingga banyak waktu yang terbuang karena harus melakukan proses dari awal. Selain itu, dampak negatif lainnya adalah kualitas dan kemampuan untuk menggantikan karyawan yang keluar dari perusahaan, sehingga butuh waktu serta biaya dalam merekrut karyawan baru (Muafi dan Nilmawati, 2014 dalam Fadzilah, 2016).

Tingginya tingkat keinginan berpindah karyawan diduga terjadi karena tidak tercapainya harapan-harapan karyawan terhadap keberlangsungan pekerjaannya yang mencakup hal-hal seperti: adanya kesempatan promosi, kondisi pekerjaan pada umumnya dan kesempatan karir jangka panjang. Bagi karyawan yang masih sendiri, penghasilan bukan hal mutlak karena beban yang ditanggung hanya sendiri. Akan tetapi hal ini akan berbeda ketika karyawan telah berkeluarga, keamanan dalam bekerja menjadi prioritas utama karena berdampak sangat besar dalam kehidupan karyawan dan keluarga yang menjadi tanggung jawabnya (Widodo, 2010 dalam Fadzilah, 2016).

Salah satu faktor yang menyebabkan keinginan untuk berpindah adalah ketidakamanan kerja. Di Indonesia, banyak perusahaan yang masih menggunakan tenaga kerja kontrak. Posisi tawar karyawan relatif rendah sehingga bagi karyawan mendapat pekerjaan sementara dalam kontrak kerja sudah dianggap masih lebih baik daripada menganggur (Halimah, 2016). Hal tersebut merupakan salah satu faktor yang dapat mengakibatkan makin meningkatnya job insecurity yang dialami karyawan. Tidak jarang karyawan memutuskan keluar dari perusahaan sebelum habis masa kontrak. Selain itu perusahaan juga menerapkan penilaian kinerja karyawan satu minggu sebelum kontrak habis. Jika karyawan diketahui melakukan pelanggaran melebihi standar yang ditetapkan, maka karyawan dipecat. Hal inilah salah satu penyebab karyawan merasa terancam, gelisah, dan kurang adanya jaminan dari perusahaan yang berujung pada job insecurity. Karyawan yang mengalami rasa tidak aman yang makin meningkat karena ketidakstabilan terhadap status kepegawaian dan tingkat pendapatan yang makin tidak bisa diramalkan, akibatnya intensi turnover cenderung meningkat.

Ketika lingkungan kerja disuatu perusahaan tidak kondusif untuk bekerja, maka karyawan dipastikan tidak akan bertahan lama di perusahaan tersebut. Perusahaan harus berusaha sekuat tenaga agar pramuniaga terbaiknya bertahan. Hal yang paling mungkin 


\section{Buletin Ekonomi}

dilakukan oleh perusahaan adalah menjaga mereka agar tetap merasa nyaman dengan lingkungan kerja di perusahaan. Tidak hanya lingkungan kerja fisik tetapi dalam hal psikologisnya pun harus diperhatikan. Lingkungan kerja yang kondusif, akan membuat karyawan merasa nyaman dalam melaksanakan tugasnya. Lingkungan kerja yang buruk, seperti sedikitnya fasilitas yang didapat pramuniaga, tidak adanya tempat untuk istirahat pramuniaga, akan semakin mendorong niat karyawan untuk mengundurkan diri. Semakin lengkap fasilitas yang diterima untuk menunjang pekerjaannya maka semakin rendah niat mereka untuk mencari alternatif pekerjaan lain (Halimah, 2016).

Ketidakpuasan kerja sering berujung pada keinginan untuk keluar dari perusahaan. Salah satu faktor yang menyebabkan ketidakpuasan kerja ialah sifat atasan yang tidak mau mendengar keluhan. Kurangnya komunikasi langsung antara atasan dengan karyawan seringkali membuat atasan tidak memahami apa yang dirasakan dan diinginkan oleh mereka. Ketika hubungan antara karyawan dengan atasan terjalin dengan baik maka tingkat turnover intention dapat ditekan dan cenderung menurun (Halimah, 2016). Kepuasan kerja karyawan salah satunya dapat dicapai dengan memperhatikan gaji yang diterima. Ketika gaji yang diterima dapat mencukupi kebutuhan maka dapat menurunkan keinginan karyawan untuk keluar dari perusahaan. Kesesuaian pemberian gaji dan insentif sangat penting agar karyawan merasa sesuai dan puas dengan apa yang telah mereka lakukan untuk perusahaan. Dapat diartikan bahwa apabila kepuasan terhadap gaji tinggi maka makin rendah niat untuk keluar.

Komitmen organisasional merupakan hal penting bagi perusahaan karena disinyalir sebagai prediktor yang lebih baik bagi keinginan berpindah dibandingkan dengan kepuasan kerja. Terdapat tiga indikator dalam komitmen organisasi, yaitu: keinginan kuat tetap sebagai anggota, keinginan berusaha keras, keyakinan tertentu, penerimaan nilai organisasi dan tujuan organisasi. Individu yang memiliki komitmen organisasional yang rendah cenderung untuk mencari kesempatan kerja yang lebih baik dan keluar dari pekerjaannya, karena dalam diri mereka telah tertanam keinginan untuk keluar organisasi (Fadzilah, 2016).

Ketatnya persaingan bisnis menyebabkan pihak manajemen Java Dancer Coffee (salah satu coffee shop ternama di kota Malang), menerapkan kebijakan dalam pengambilan keputusan terkait dengan karyawan. Penerimaan karyawan di Java Dancer Coffee dibagi dalam 3 golongan, yaitu karyawan tetap, karyawan kontrak dan karyawan part time. Hal yang melatarbelakangi permasalahan bahwa kebijakan pihak manajemen dalam pengambilan keputusan sering menjadi konflik bagi karyawan. Ketidakadilan kebijakan yang diterapkan pihak manajemen yang cenderung sepihak mendorong terjadinya konflik antara karyawan dan pihak manajemen. Dampak dengan konflik tersebut menyebabkan tingginya keinginan karyawan untuk pindah ke tempat kerja lain.

Novelty (kebaruan) penelitian ini adalah merupakan hasil eksplorasi dan kombinasi dari beberapa penelitian empiris, serta memiliki perbedaan variabel dan indikator yang telah disesuiakan dengan obyek penelitian ini.

Berdasarkan uraian di atas, maka rumusan masalah yang dapat disampaikan adalah sebagai berikut: (1) Bagaimana pengaruh job insecurity, lingkungan kerja, kepuasan kerja dan komitmen organisasi terhadap turnover intention karyawan secara parsial?; dan (2) Bagaimana pengaruh job insecurity, lingkungan kerja, kepuasan kerja dan komitmen organisasi terhadap turnover intention karyawan secara simultan?

Adapun manfaat penelitian antara lain: (1) Sebagai bahan masukan bagi manajemen Java Dancer Coffee Malang berkaitan dengan issue manajemen sumber daya manusia, khsususnya tentang job insecurity, lingkungan kerja, kepuasan kerja dan komitmen organisasi. Sehingga dapat menjadi landasan strategi human resource development ke depannya; (2) Menambah dan mengasah wawasan peneliti khususnya dalam hal manajemen sumber daya manusia; dan (3) Hasil dari penelitian ini diharapkan dapat menjadi referensi 


\section{Buletin Ekonomi}

atau masukan bagi perkembangan ilmu manajemen sumber daya manusia dan menambah kajian ilmu manajemen sumber daya manusia.

Pane, Sri Gustina (2013) menganalisis pengaruh job insecurity, komitmen organisasi, lingkungan kerja dan kepuasan kerja terhadap intent to quit dosen dan pegawai di Universitas Islam Sumatera Utara, dengan sampel 125 orang. Hasil penelitian membuktikan bahwa ada pengaruh positif dan signifikan antara job insecurity terhadap intent to quit dosen dan pegawai. Sedangkan lingkungan kerja dan kepuasan kerja berpengaruh negatif terhadap intent to quit, job security berpengaruh negatif terhadap komitmen organisasi, tetapi memiliki pengaruh positif terhadap intent to quit.

Mawei, Ronald (2016) dalam penelitiannya membuktikan bahwa job insecurity berpengaruh signifikan terhadap intent to quit karyawan outsourcing PT PLN Manado. Komitmen karyawan tidak signifikan berpengaruh terhadap intent to quit, sedangkan kepuasan kerja berpengaruh signifikan terhadap intent to quit. Tsani, Renny Rakhma (2016) dalam penelitiannya membuktikan bahwa lingkungan kerja dan kepuasan kerja secara positif dan signifikan berpengaruh terhadap turnover intention. Penelitian lain yang dilakukan oleh Fadzillah (2016) menunjukkan bahwa ketidakamanan kerja berpengaruh positif signifikan pada keinginan berpindah, sedangkan komitmen organisasi dan kepercayaan organisasi berpengaruh negatif signifikan. Semakin tinggi ketidak amanan kerja akan meningkatkan keinginan berpindah, dan semakin tinggi komitmen serta kepercayaan organisasional akan menurunkan keinginan berpindah.

Penelitian Halimah, Tika Nur (2016) meneliti pada 80 pramuniaga Gelael Supermarket Superindo di Semarang. Layanan yang diberikan oleh karyawan Gelael diharapkan dapat memberikan kepuasan pelanggan. Karyawan diharapkan menjadi nyaman bekerja di Gelael Semarang sehingga pelayanan dapat dimaksimalkan. Hasil penelitian membuktikan bahwa ketidakamanan kerja, kepuasan kerja dan lingkungan kerja berpengaruh negatif terhadap turnover intention.

Smithson dan Lewis (2000) mengartikan job insecurity sebagai kondisi psikologis seseorang (karyawan) yang menunjukkan rasa bingung atau merasa tidak aman dikarenakan kondisi lingkungan yang berubah-ubah (perceived impermanance). Kondisi ini muncul karena banyaknya jenis pekerjaan yang sifatnya sesaat atau pekerjaan kontrak. Makin banyaknya jenis pekerjaan dengan durasi waktu yang sementara atau tidak permanen, menyebabkan semakin banyaknya karyawan yang mengalami job insecurity. Chirumbolo, Areni (2005) menjelaskan beberapa definisi penting mengenai job insecurity di antaranya menurut Hellgren, Sverke dan Isaksson yang membedakan dua bentuk ketidakamanan kerja yaitu ketidakamanan pekerjaan kuantitatif, yaitu khawatir tentang kehilangan pekerjaan itu sendiri, dan perasaan khawatir kehilangan pekerjaan. Sementara ketidakamanan pekerjaan kualitatif mengacu pada perasaan potensi kerugian dalam kualitas posisi organisasi, seperti memburuknya kondisi kerja, kurangnya kesempatan karir, penurunan gaji pengembangan (Sverke \& Hellgren, 2002).

Komponen yang mengakibatkan timbulnya job insecurity adalah: (1) Tingkat ancaman yang dirasakan karyawan mengenai aspek-aspek pekerjaan seperti kemungkinan untuk mendapat promosi, mempertahankan tingkat upah yang sekarang, atau memperoleh kenaikan upah. Individu yang menilai aspek kerja tertentu yang terancam (terdapat kemungkinan aspek kerja tersebut akan hilang) akan lebih gelisah dan merasa tidak berdaya; (2) Arti pekerjaan itu bagi individu. Seberapa pentingnya aspek kerja tersebut bagi individu mempengaruhi tingkat insecure atau rasa tidak amannya; (3) Tingkat ancaman kemungkinan terjadinya peristiwa-peristiwa yang secara negatif mempengaruhi keseluruhan kerja individu, misalnya dipecat atau dipindahkan ke kantor cabang yang lain; (4) Tingkat kepentingan yang dirasakan individu mengenai potensi setiap peristiwa tersebut. 


\section{Buletin Ekonomi}

Dari hasil beberapa studi yang dilakukan Greenglass (2002), ditemukan adanya pengaruh job insecurity terhadap karyawan, di antaranya: (1) Meningkatnya ketidakpuasan dalam bekerja; (2) Meningkatnya gangguan fisik; (3) Meningkatnya gangguan psikologis. Penurunan kondisi kerja seperti rasa tidak aman (insecure) menurunkan kualitas individu bukan dari pekerjaannya semata, namun juga mengarahkan pada munculnya rasa kehilangan martabat (demotion) yang pada akhirnya menurunkan kondisi psikologis dari karyawan yang bersangkutan. Jangka panjangnya akan muncul ketidakpuasan dalam bekerja dan akan mengarah pada intensi; (4) Karyawan cenderung menarik diri dari lingkungan kerjanya. Makin berkurangnya komitmen organisasi. Job insecurity juga mempengaruhi komitmen kerja dan perilaku kerja. Individu yang bisa melalui tahapan kritis dari rasa tidak aman akan makin berkurang komitmennya; dan (5) Peningkatan jumlah karyawan yang berpindah (employee turnover)

Hasil studi oleh Pasewark dan Strawser (dalam Suwandi \& Indriartoro,1999) mengidentifikasi tiga penyebab job insecurity yang dihadapi karyawan: (1) Konflik Peran; (2) Ketidakjelasan Peran; dan (3) Locus of Control. Indikator/dimensi yang digunakan untuk mengukur job insecurity menurut Hallgnen, et al (1998) dalam Aswad (2011) yaitu: (1) Status seseorang dalam jabatan; (2) Usia; (3) Jadwal pekerjaan; dan (4) Upah

Menurut Sedarmayati (2009:21) definisi lingkungan kerja adalah keseluruhan alat perkakas dan bahan yang dihadapi, lingkungan sekitarnya di mana seseorang bekerja, metode kerjanya, serta pengaturan kerjanya baik sebagai perseorangan maupun sebagai kelompok. Menurut Sarwono (2005), "Lingkungan kerja adalah lingkungan dimana pegawa/karyawan melakukan pekerjaannya sehari-hari”. Lingkungan kerja yang kondusif memberikan rasa aman dan memungkinkan para pegawai untuk dapat berkerja optimal. Lingkungan kerja dapat mempengaruhi emosi pegawai. Jika pegawai menyenangi lingkungan kerja dimana dia bekerja, maka pegawai tersebut akan betah di tempat kerjanya untuk melakukan aktivitas sehingga waktu kerja dipergunakan secara efektif dan optimis prestasi kerja pegawai juga tinggi. Lingkungan kerja tersebut mencakup hubungan kerja yang terbentuk antara sesama pegawai dan hubungan kerja antar bawahan dan atasan serta lingkungan fisik tempat pegawai bekerja.

Lingkungan kerja dapat dibagi atas 2 (dua) jenis, yaitu: lingkungan kerja non fisik dan lingkungan kerja fisik (Nurhaida, 2010; Novita, 2013). Lingkungan kerja non fisik mencakup hubungan kerja yang terbina dalam perusahan (Sedarmayanti, 209). Seseorang bekerja di dalam perusahan tidaklah seorang dir, dan dalam melakukan aktivitas, orang tersebut juga membutuhkan bantuan orang lain. Menurut Sedarmayanti (2009: 21) "secara garis besar, jenis lingkungan kerja terbagi menjadi 2 yakni: lingkungan kerja fisik dan lingkungan kerja non fisik".

Menurut Ishak dan Tanjung (2003:26), manfaat lingkungan kerja adalah menciptakan gairah kerja, sehingga produktivitas dan prestasi kerja meningkat. Sementara itu, manfaat yang diperoleh karena bekerja dengan orang-orang yang termotivasi adalah pekerjaan dapat diselesaikan dengan tepat. Yang artinya pekerjaan diselesaikan sesuai standard yang benar dan dalam skala waktu yang ditentukan. Prestasi kerjanya akan dipantau oleh individu yang bersangkutan, dan tidak akan menimbulkan terlalu banyak pengawasan serta semangat juangnya akan tinggi.

Menurut Luthans (2006:243), kepuasan kerja adalah keadaan emosional yang merupakan hasil dari evaluasi pengalaman kerja seseorang. Menurut pendapat Robbins dan Judge (2007) mengatakan bahwa kepuasan kerja adalah suatu sikap umum individu terhadap pekerjaanya dimana dalam pekerjaan tersebut seseorang dituntut untuk berinteraksi dengan rekan kerja dan atasan, mengikuti aturan dan kebijaksanaan organisasi memenuhi standar kinerja. Menurut Hasibuan (2010:202), kepuasan kerja adalah "sikap emosional yang 


\section{Buletin Ekonomi}

menyenangkan dan mencintai pekerjaannya". Dari definisi-definisi di atas dapat disimpulkan bahwa kepuasan kerja merupakan perasaan emosional karyawan terhadap pekerjaannya atas ganjaran dan lingkungan.

Adapun indikator-indikator kepuasan kerja menurut Hasibuan (2001) antara lain: (1) Kesetiaan. Penilai mengukur kesetiaan karyawan terhadap pekerjaannya, jabatannya, dan organisasi. Kesetiaan ini dicerminkan oleh kesediaan karyawan menjaga dan membela organisasi di dalam maupun di luar pekerjaan dari rongrongan orang yang tidak bertanggung jawab; (2) Kemampuan. Penilai menilai hasil kerja baik kualitas maupun kuantitas yang dapat dihasilkan karyawan tersebut dari uraian pekerjaannya; (3) Kejujuran. Penilai menilai kejujuran dalam melaksanakan tugas-tugasnya memenuhi perjanjian baik bagi dirinya sendiri maupun terhadap orang lain; (4) Kreatifitas. Penilai menilai kemampuan karyawan dalam mengembangkan kreativitasnya untuk menyelesaikan pekerjaannya, sehingga akan dapat bekerja lebih baik; (5) Kepemimpinan. Penilai menilai kemampuan untuk memimpin, mempunyai pribadi yang kuat, dihormati, berwibawa, dan dapat memotivasi orang lain atau bawahannya untuk bekerja secara efektif; (6) Tingkat Gaji. Penilai menilai jumlah gaji yang diberikan perusahaan dan diterima karyawan harus sesuai dengan apa yang karyawan berikan kepada perusahaan agar mereka merasa puas; (7) Kompensasi Tidak Langsung. Penilai menilai pemberian balas jasa yang memadai dan layak kepada para karyawan atas kontribusi mereka membantu perusahaan mencapai tujuannya. Pemberian balas jasa atau imbalan atas tenaga, waktu, pikiran serta prestasi yang telah diberikan seseorang kepada perusahaan; dan (8) Lingkungan Kerja. Penilai menilai lingkungan kerja yang baik dapat membuat karyawan merasa nyaman dalam bekerja.

Mangkunegara (2009:120) mengatakan ada dua faktor yang mempengaruhi kepuasan kerja, yaitu faktor yang ada pada diri pegawai dan faktor pekerjaannya. (1) Faktor Pegawai. Faktor pegawai meliputi kecerdasan (IQ), kecakapan khusus, umur, jenis kelamin, kondisi fisik, pendidikan, pengalaman kerja, masa kerja, kepribadian, emosi, cara berpikir, persepsi, dan sikap kerja; dan (2) Faktor Pekerjaan. Faktor pekerjaan ini terdiri dari jenis pekerjaan, struktur organisasi, pangkat (golongan), kedudukan, mutu pengawasan, jaminan finansial, kesempatan promosi jabatan, interaksi sosial, dan hubungan kerja.

Robbins dan Judge (2007) mendefinisikan komitmen sebagai suatu keadaan dimana seorang individu memihak organisasi serta tujuan-tujuan dan keinginannya untuk mempertahankan keangotaannya dalam organisasi. Sedangkan Mathis dan Jackson (dalam Sopiah, 155) mendefinisikan komitmen organisasional sebagai derajad dimana karyawan percaya dan mau menerima tujuan-tujuan organisasi dan akan tetap tinggal atau tidak akan meninggalkan organisasinya. Richard M. Steers (dalam Sri Kuntjoro, 2002) mendefinisikan komitmen organisasi sebagai rasa identifikasi (kepercayaan terhadap nilai-nilai organisasi), keterlibatan (kesediaan untuk berusaha sebaik mungkin demi kepentingan organisasi) dan loyalitas (keinginan untuk tetap menjadi anggota organisasi yang bersangkutan) yang dinyatakan oleh seorang pegawai terhadap organisasinya. Dari beberapa definisi yang diuraikan di atas dapat disimpulkan bahwa komitmen merupakan suatu ikatan psikologis karyawan pada organisasi ditandai dengan adanya: (1) Kepercayaan dan penerimaan yang kuat terhadap tujuan dan nilai-nilai organisasi; (2) Kemauan untuk mengusahakan tercapainya kepentingan organisasi; dan (3) Keinginan yang kuat untuk mempertahankan kedudukan sebagai anggota organisasi.

Mowday yang dikutip Sopiah (2008) menyatakan ada tiga aspek komitmen antara lain: (1) Affective commitment, yang berkaitan dengan adanya keinginan untuk terikat pada organisasi. Individu menetap dalam organisasi karena keinginan sendiri. Kunci dari komitmen ini adalah (want to); (2) Continuance commitment adalah suatu komitmen yang didasarkan akan kebutuhan rasional. Dengan kata lain, komitmen ini terbentuk atas dasar 


\section{Buletin Ekonomi}

untung rugi, dipertimbangkan atas apa yang harus dikorbankan bila akan menetap pada suatu organisasi. Kunci dari komitmen ini adalah kebutuhan untuk bertahan (need to); dan (3) Normative Commitment adalah komitmen yang didasarkan pada norma yang ada dalam diri karyawan, berisi keyakinan individu akan tanggung jawab terhadap organisasi. Ia merasa harus bertahan karena loyalitas. Kunci dari komitmen ini adalah kewajiban untuk bertahan dalam organisasi (ought to).

Komitmen pegawai pada organisasi tidak terjadi begitu saja, tetapi melalui proses yang cukup panjang dan bertahap. Steers (dalam Sopiah, 2008) menyatakan tiga faktor yang mempengaruhi komitmen seorang karyawan antara lain: (1) Ciri pribadi pekerja termasuk masa jabatannya dalam organisasi, dan variasi kebutuhan dan keinginan yang berbeda dari tiap karyawan; (2) Ciri pekerjaan, seperti identitas tugas dan kesempatan berinteraksi dengan rekan sekerja; dan (3) Pengalaman kerja, seperti keterandalan organisasi di masa lampau dan cara pekerja-pekerja lain mengutarakan dan membicarakan perasaannya tentang organisasi.

Turnover intention (intensi keluar) adalah kecenderungan atau niat karyawan untuk berhenti bekerja dari pekerjaannya (Zeffane, 1994 dalam Halimah, 2016). Menurut Mobley et al (1978) keinginan pindah kerja adalah kecenderungan atau niat karyawan untuk berhenti bekerja dari pekerjaannya secara sukarela atau pindah dari satu tempat kerja ke tempat kerja yang lain menurut pilihannya sendiri. Harnoto (2002) menyatakan: "Turnover intentions adalah kadar atau intensitas dari keinginan untuk keluar dari perusahaan, banyak alasan yang menyebabkan timbulnya turnover intentions ini dan di antaranya adalah keinginan untuk mendapatkan pekerjaan yang lebih baik." Pendapat tersebut juga relatif sama dengan pendapat yang telah diungkapkan sebelumnya, bahwa turnover intentions pada dasarnya adalah keinginan untuk meninggalkan (keluar) dari perusahaan.

Menurut Harnoto (2002:2) "Turnover intentions ditandai oleh berbagai hal yang menyangkut perilaku karyawan, antara lain: absensi yang meningkat, mulai malas kerja, naiknya keberanian untuk melanggar tata tertib kerja, keberanian untuk menentang atau protes kepada atasan, maupun keseriusan untuk menyelesaikan semua tanggung jawab karyawan yang sangat berbeda dari biasanya." Indikasi-indikasi tersebut bisa digunakan sebagai acuan untuk memprediksikan turnover intentions karyawan dalam sebuah perusahaan: (1) Absensi yang meningkat; (2) Mulai malas bekerja; (3) Peningkatan terhadap pelanggaran tatatertib kerja; (4) Peningkatan protes terhadap atasan; dan (5) Perilaku positif yang sangat berbeda dari biasanya.

Menurut Staffelbach (2008), faktor-faktor penyebab turnover intention dikategorikan sebagai berikut:

Faktor psikologi

Menurut Brinkmann dan Stapf (2005), faktor psikologi, yaitu: (1) Kontrak psikologis atau psychological contract mengacu pada keyakinan individu mengenai syarat dan ketentuan perjanjian timbal balik pertukaran antara seseorang dan pihak lain. Konsep kontrak psikologis didasarkan pada wawasan, bahwa motivasi karyawan dan tingkat kinerja mereka harus dipelihara oleh organisasi melalui insentif dan penghargaan. Kontrak psikologis berisi semua harapan timbal yang balik tidak terungkapkan, harapan dan keinginan karyawan atau atasan dan merupakan perjanjian tambahan tidak dirumuskan dalam pekerjaan yang mengikat kontrak sah; (2) Kepuasan kerja. Kepuasan kerja adalah keadaan emosional menyenangkan yang dihasilkan dari penilaian pekerjaan seseorang dalam mencapai atau memfasilitasi pencapaian nilai pekerjaannya. Kepuasan kerja menjadi terikatan efektif seseorang, hal ini dikonseptualisasikan sebagai respon afektif dan emosional; (3) Komitmen organisasi. Komitmen dapat dilihat sebagai loyalitas sebuah organisasi atau suatu pekerjaan. Meyer dan Allen mengkonsepkan komitmen dalam tiga keadaan psikologis yang berbeda yang 


\section{Buletin Ekonomi}

mempengaruhi apakah karyawan akan tetap atau meninggalkan organisasi, yaitu: (a) Komitmen afektif: keterikatan emosional terhadap organisasi; (b) Komitmen berkelanjutan: pengakuan biaya yang terkait dengan meninggalkan organisasi; (c) Komitmen normatif: kewajiban yang dirasakan untuk tetap dengan organisasi; (4) Ketidakamanan kerja atau job insecurity. Job insecurity sebagai kekhawatiran pribadi tentang kelangsungan pekerjaan. Karyawan dapat merasa tidak aman meskipun tidak ada alasan untuk itu. Namun, ketidakamanan pekerjaan lebih dikenal sebagai ketidakpastian tentang pekerjaan di masa depan dalam pengembangan pekerjaan dan juga diskontinuitas.

Faktor ekonomi

Berupa: (1) Upah. Upah pembayaran memainkan peran penting dalam pekerjaan pada masa ini dan masa depan. Bahwa karyawan yang dibayar lebih tinggi dalam tingkat hirarki yang sama cenderung untuk tetap bertahan dalam organisasi (Poza, 2007); (2) Peluang eksternal. Peluang eksternal mengacu pada tersedianya alternatif, daya tarik dan pencapaian dari pekerjaan di lingkungan. Interaksi antara kekuatan penawaran dan permintaan ekonomi harus dipertimbangkan dalam mengukur peluang eksternal. Ketersediaan ini terutama tentang seberapa banyak peluang di luar organisasi. C. Ukuran perusahaan atau company size

Faktor demografis

Faktor demografis yang sering disebut juga sebagai karakteristik personal yang terdiri dari: (1) Usia. Faktor usia berkolerasi negatif dengan turnover intention (Poza, 2007). Orang yang lebih muda memiliki tahap percobaan pada awal kehidupan profesional mereka, sehingga lebih sering berpindah kerja; dan (2) Masa jabatan. Individu yang memiliki masa jabatan lebih lama kemudian meninggalkan organisasi akan dianggap tidak proporsional.

Hanafiah dalam Fadzilah (2016) menyatakan ada banyak faktor yang membuat individu memiliki keinginan untuk berpindah. Faktor-faktor tersebut di antaranya adalah kepuasan kerja, komitmen organisasi, ketidakamanan kerja dan lingkungan kerja. Ketidakamanan kerja (job insecurity) merupakan perasaan tertekan yang dirasakan karyawan mengenai tidak tercapainya harapan-harapan mereka terhadap keberlangsungan pekerjaannya. Faktor ketidakamanan kerja berperan besar terhadap terjadinya keinginan berpindah dalam perusahaan atau organisasi. Jadi jika karyawan merasa suatu tingkat ancaman yang tinggi terhadap aspek pekerjaan dan keseluruhan pekerjaannya, maka semakin tinggi pula keinginan karyawan untuk berpindah kerja.

Seseorang mempunyai keinginan untuk berpindah dari pekerjaan juga karena sudah tidak ada komitmen dari karyawan untuk tetap bekerja dalam perusahaan. Karyawan yang memenuhi komitmen organisasi akan memiliki tingkat keinginan berpindah yang semakin rendah. Semakin tinggi komitmen organisasi diharapkan akan menurunkan maksud atau tujuan karyawan untuk meninggalkan organisasi. 
Berdasarkan uraian di atas maka dibuatlah model hipotesis sebagai berikut:

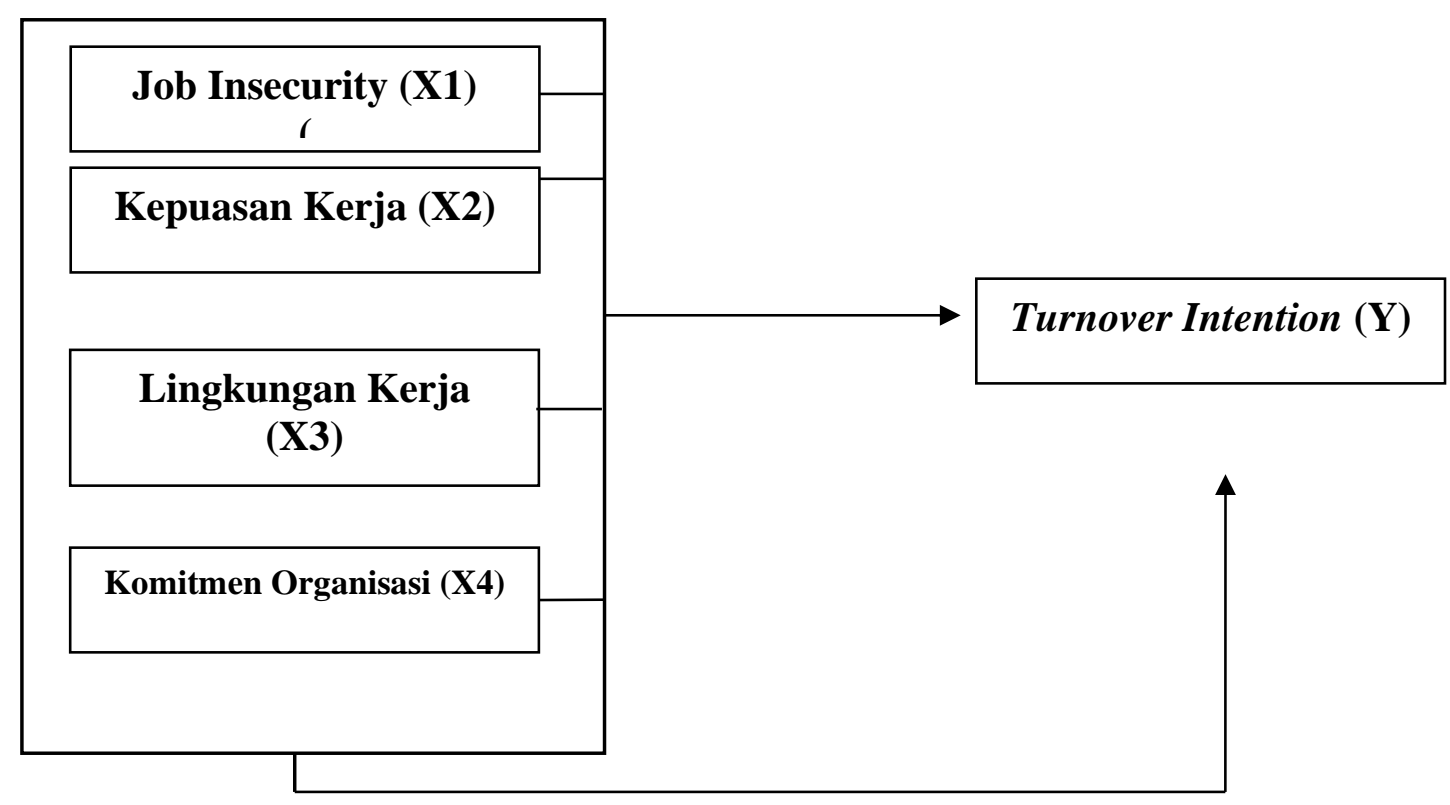

Gambar 1. Model Hipotesis

Adapun hipotesis dalam penelitian ini adalah:

$\mathrm{H}_{1}$ : Diduga ada pengaruh secara simultan antara Job Insecurity, Lingkungan Kerja, Kepuasan Kerja dan Komitmen Organisasi terhadap Turnover Intention

$\mathrm{H}_{2}$ : Diduga ada pengaruh secara parsial Job Insecurity, Lingkungan Kerja, Kepuasan Kerja dan Komitmen Organisasi terhadap Turnover Intention.

\section{METODE}

Penelitian ini dilakukan di seluruh outlet Java Dancer Coffee Malang:

1. Java Dancer Coffee J1. Kahuripan 52, Malang

2. Java Dancer Coffee Roastery J1. Jakarta 59, Malang

3. Java Dancer Coffee "Bel Canto" Jl. Veteran 2, Malang Town Square P9, Malang

4. Java Dancer Coffee "Bel Canto", Jatim Park 3, Batu, Malang

Populasi menurut Arikunto (2010) adalah keseluruhan dari banyaknya obyek yang akan diteliti. Populasi yang digunakan dalam penelitian ini adalah seluruh karyawan Java Dancer Coffee Malang sebanyak 113 karyawan meliputi:

a. Karyawan Tetap sebanyak 32 orang

b. Karyawan Kontrak sebanyak 50 orang

c. Karyawan Parttime sebanyak 31 orang

Sampel menurut Arikunto (2006: 131 adalah sebagian atau wakil populasi yang diteliti. Jika kita hanya akan meneliti sebagian dari populasi, maka penelitian tersebut disebut penelitian sampel. Teknik pengambilan sampel yang digunakan adalah Random Sampling atau acak. Dalam penelitian ini batas error yang digunakan adalah 10\%, dari karyawan Java Dancer Coffee. Untuk itu rumus yang digunakan yaitu Rumus Slovin sebagai berikut: 


\section{Buletin Ekonomi}

$$
\begin{aligned}
& \mathrm{n}=\frac{\mathrm{N}}{1+\mathrm{N}(\mathrm{e})^{2}} \\
& \mathrm{n}=\frac{113}{1+113(0,1)^{2}} \\
& \mathrm{n}=\frac{113}{1+1,13} \\
& \mathrm{n}=53,05
\end{aligned}
$$

Keterangan :

$\begin{array}{lll}\mathrm{n} & = & \text { Jumlah sampel } \\ \mathrm{N} & = & \text { Jumlah populasi } \\ \mathrm{e} & = & \text { Nilai kritis (batas ketelitian) yang diinginkan } \\ 1 & = & \text { Bilangan konstan }\end{array}$

Jadi, sampel yang digunakan yaitu 53 orang karyawan Java Dancer Coffee Malang tanpa memperhatikan tingkatan, usia dan jenis kelamin.

Dalam penelitian ini terdapat empat varibel bebas yaitu:

a. Job Insecurity (X1)

$\mathrm{Job}$ insecurity sebagai kondisi psikologis seseorang (karyawan) yang menunjukkan rasa bingung atau merasa tidak aman dikarenakan kondisi lingkungan yang berubah-ubah (perceived impermanance), dengan item-item sebagai berikut:

1) Konflik peran

2) Ketidakjelasan peran

3) Jadwal pekerjaan

4) Gangguan psikologis

5) Status seseorang dalam pekerjaan

b. Lingkungan Kerja (X2)

Lingkungan kerja merupakan tempat dimana para karyawan melakukan aktivitas bekerja, item-item lingkungan kerja adalah sebagai berikut:

1) Ukuran ruang kerja

2) Pengaturan ruang kerja

3) Privasi

4) Komunikasi

5) Hubungan dengan rekan kerja

c. Kepuasan Kerja (X1)

Kepuasan kerja adalah keadaan emosional yang merupakan hasil dari evaluasi pengalaman kerja seseorang, item-item kepuasan kerja adalah sebagai berikut:

1) Kesempatan promosi jabatan

2) Pekerjaan itu sendiri

3) Lingkungan kerja

4) Kepemimpinan

5) Kompensasi

\section{d. Komitmen Organisasi (X4)}

Komitmen organisasional sebagai derajad dimana karyawan percaya dan mau menerima tujuan-tujuan organisasi dan akan tetap tinggal atau tidak akan meninggalkan organisasinya, item-item komitmen organisasi adalah sebagai berikut:

1) Keinginan untuk terikat pada organisasi

2) Keinginan untuk terus bertahan pada organisasi

3) Rasa tanggungjawab terhadap organisasi 


\section{Buletin Ekonomi}

4) Pengalaman kerja

5) Kedudukan dalam organisasi

Variabel Terikat (Dependen) penelitian ini yaitu Turnover Intention (Y), yaitu kadar atau intensitas dari keinginan untuk keluar dari perusahaan, Item-item turnover intention adalah sebagai berikut:
1) Tingkat upah
2) Sikap atasan
3) Ketertarikan masa depan terhadap pekerjaan saat ini
4) Pengakuan dan penghargaan
5) Keterlibatan karyawan dalam organisasi

\section{Uji Validitas dan Reliabilitas}

Uji validitas digunakan untuk mengukur sah atau valid tidaknya suatu kuesioner. Suatu kuesioner dikatakan valid jika pertanyaan pada kuesioner mampu untuk mengungkapkan sesuatu yang akan diukur oleh kuesioner tersebut (Ghozali, 2005). Untuk mengukur validitas dapat dilakukan dengan melakukan korelasi antar skor butir pertanyaan dengan total skor konstruk atau variabel. Sedangkan untuk mengetahui skor masing - masing item pertanyaan valid atau tidak, maka ditetapkan kriteria statistic sebagai berikut:

1. Jika $r$ hitung $>r$ tabel dan bernilai positif, maka variabel tersebut valid.

2. Jika $r$ hitung $<\mathrm{r}$ tabel, maka variabel tersebut tidak valid.

3. Jika $r$ hitung $>r$ tabel tetapi bertanda negatif, maka $\mathrm{HO}$ akan tetap ditolak dan H1 diterima.

Uji reliabilitas adalah alat untuk mengukur suatu kuisioner yang mempunyai indikator dari variabel atau konstruk. Suatu konstruk atau variabel dikatakan reliabel jika memberikan nilai Cronbanch Alpha > 0,60 (Ghozali,2005).

Asumsi Klasik merupakan salah satu pengujian prasyarat pada regresi linear berganda. Menurut Kuncoro (2013), suatu model regresi yang valid harus memenuhi kriteria BLUE (Best, Linear, Unbiased, and Estimated). Uji prasyarat regresi linear berganda, yaitu uji Asumsi Klasik. Asumsi Klasik pada umumnya terdiri dari Normalitas, Multikolinearitas, Autorkorelasi, dan Heteroskedastisitas pada model regresi linear berganda.

Analisis kuantitatif merupakan alat statistik berupa analisis linier berganda, mengandung makna bahwa suatu persamaan regresi terdapat satu variabel dependen atau lebih satu variabel independen (Algifari, 2000:62). Jadi analisis regresi linier ganda akan dilakukan bila jumlah variabel independennya minimal dua (2). Persamaan regresi adalah: Dari data linier yang telah diolah mengggunakan SPSS maka akan disusun persamaan linier yang diberikan dalam penelitian ini hanya melibatkan empat variabel yaitu satu variabel dependen dan tiga variabel independen sebagai berikut :

$$
Y=\beta_{0}+\beta_{1} X_{1}+\beta_{2} X_{2}+\beta_{3} X_{3}+\beta_{4} X_{4}+e
$$

Keterangan:

$\mathrm{Y} \quad=$ Variabel Terikat (Turnover Intention)

$\mathrm{X}_{1} \quad=$ Variabel Bebas (Job Insecurity)

$\mathrm{X}_{2} \quad=$ Variabel Bebas (Lingkungan Kerja)

$\mathrm{X}_{3}=$ Variabel Bebas (Kepuasan Kerja)

$\mathrm{X}_{4} \quad=$ Variabel Bebas (Komitmen Organisasi)

$\beta_{0} \quad=$ Intercept (nilai rata-rata pada variabel Y)

$\beta_{1} \quad=$ Slope $($ koefisien regresi untuk variabel $\mathrm{X}$ )

e $=$ error $/$ variabel pengganggu 


\section{Buletin Ekonomi}

\section{Uji Hipotesis}

Uji Hipotesis adalah cabang Ilmu Statistika Inferensial yang dipergunakan untuk menguji kebenaran suatu pernyataan secara statistik dan menarik kesimpulan apakah menerima atau menolak pernyataan tersebut. Pernyataan ataupun asumsi sementara yang dibuat untuk diuji kebenarannya tersebut dinamakan dengan Hipotesis (Hypothesis) atau Hipotesa.

\section{Uji Signifikansi Simultan (Uji F)}

Untuk mengetahui hubungan yang simultan maka dilakukan uji statistik F. Uji hipotesis dengan uji F signifikansi digunakan untuk mengetahui apakah variabel independen signifikan atau tidak terhadap variabel dependen secara individual untuk setiap variabel. Penggunaan tingkat signifikansinya beragam, tergantung keinginan peneliti, yaitu $0,01(1 \%) ; 0,05(5 \%)$ dan $0,10(10 \%)$. Hasil uji $\mathrm{F}$ dilihat dalam tabel ANOVA dalam kolom sig. Level signifikan yang digunakan dalam penelitian ini adalah 5\%. Kriteria pengambilan keputusan sebagai berikut:

Bila F hitung > F tabel maka hipotesis nol (0)ditolak

Bila $\mathrm{F}$ hitung $<\mathrm{F}$ tabel maka hipotesis nolditerima

Dalam hal ini digunakan $\alpha=5 \%$, untuk menunjukkan adanya nilai konstanta maupun koefisien regresi bersifat signifikan atau tidak.

\section{Uji Signifikansi Pengaruh Parsial (Uji t)}

Uji-t dilakukan untuk mengetahui seberapa besar pengaruh variabel independen terhadap variabel dependen secara parsial (Ghozali, 2005). Uji-t ini dilakukan dengan membandingkan nilai signifikan yang dihasilkan dengan alpha 0,05. Dasar pengambilan keputusan (Ghozali, 2005) adalah dengan menggunakan angka probabilitas signifikansi, yaitu:

Apabila angka probabilitas signifikansi > 0,05, maka Ho diterima dan Ha ditolak. Apabila angka probabilitas signifikansi $<0,05$, maka Ho ditolak dan Ha diterima.

\section{ANALISIS DAN PEMBAHASAN}

\section{Hasil Uji Validitas dan Reliabilitas}

Penelitian ini hasil uji validitasnya dapat dijelaskan pada Tabel Berdasarkan hasil tanggapan responden pada Tabel1.

Dari data tabel 1 dapat disimpulkan bahwa setiap item dari masing-masing variabel dikatakan valid dikarenakan r-hitung masing- masing item lebih dari r-tabel. Hasil pengujian reliabilitas dalam pengujian ini ditunjukkan pada Tabel 2.

Berdasarkan dari Tabel 2 dapat diketahui bahwa semua item pernyataan dari variabel Job Insecurity (X1), Kepuasan Kerja (X2), Lingkungan Kerja (X3), Komitmen Organisasi (X4) dan Turnover Intention (Y)mempunyai koefisien Alpha lebih dari 0,7. Dengan demikian berarti item pertanyaan untuk semua variabel tersebut dinyatakan reliabel. 
Tabel 1.

Hasil Uji Validitas

\begin{tabular}{|c|c|c|c|c|}
\hline Variabel & Item & $\begin{array}{c}\text { Koefisien } \\
\text { Korelasi } \\
\text { (r-hitung) }\end{array}$ & $r$ tabel & Keterangan \\
\hline \multirow{5}{*}{$\begin{array}{c}\text { Job Insecurity } \\
\text { (X1) }\end{array}$} & $\mathrm{X} 1.1$ & 0,668 & 0,268 & Valid \\
\hline & $\mathrm{X} 1.2$ & 0,649 & 0,268 & Valid \\
\hline & $\mathrm{X} 1.3$ & 0,644 & 0,268 & Valid \\
\hline & X1.4 & 0,742 & 0,268 & Valid \\
\hline & $\mathrm{X} 1.5$ & 0,778 & 0,268 & Valid \\
\hline Kepuasan & $\mathrm{X} 2.1$ & 0,759 & 0,268 & Valid \\
\hline \multirow{4}{*}{ Kerja (X2) } & $\mathrm{X} 2.2$ & 0,777 & 0,268 & Valid \\
\hline & $\mathrm{X} 2.3$ & 0,738 & 0,268 & Valid \\
\hline & $\mathrm{X} 2.4$ & 0,806 & 0,268 & Valid \\
\hline & $\mathrm{X} 2.5$ & 0,697 & 0,268 & Valid \\
\hline Lingkungan & X3.1 & 0,715 & 0,268 & Valid \\
\hline \multirow{4}{*}{ Kerja (X3) } & X 3.2 & 0,728 & 0,268 & Valid \\
\hline & X3.3 & 0,669 & 0,268 & Valid \\
\hline & X3.4 & 0,706 & 0,268 & Valid \\
\hline & X3.5 & 0,609 & 0,268 & Valid \\
\hline Komitmen & $\mathrm{X} 4.1$ & 0,857 & 0,268 & Valid \\
\hline Organisasi & $\mathrm{X} 4.2$ & 0,757 & 0,268 & Valid \\
\hline \multirow[t]{3}{*}{ (X4) } & $\mathrm{X} 4.3$ & 0,653 & 0,268 & Valid \\
\hline & $\mathrm{X} 4.4$ & 0,535 & 0,268 & Valid \\
\hline & $\mathrm{X} 4.5$ & 0,661 & 0,268 & Valid \\
\hline Turnover & Y1 & 0,578 & 0,268 & Valid \\
\hline \multirow[t]{4}{*}{ Intention $(\mathrm{Y})$} & $\mathrm{Y} 2$ & 0,768 & 0,268 & Valid \\
\hline & Y3 & 0,651 & 0,268 & Valid \\
\hline & Y4 & 0,784 & 0,268 & Valid \\
\hline & Y5 & 0,815 & 0,268 & Valid \\
\hline
\end{tabular}

Sumber : Data Primer Diolah, 2018

Tabel 2.

Uji Reliabilitas

\begin{tabular}{ccc}
\hline Variabel & Cronbach alpha & Keterangan \\
\hline Job Insecurity (X1) & 0,773 & Reliabel \\
Kepuasan Kerja (X2) & 0,794 & Reliabel \\
Lingkungan Kerja (X3) & 0,771 & Reliabel \\
Komitmen Organisasi (X4) & 0,777 & Reliabel \\
Turnover Intention (Y) & 0,783 & Reliabel \\
\hline
\end{tabular}

Sumber : Data Primer Diolah | 2018

\section{Uji Asumsi Klasik}

Uji normalitas bertujuan tujuan untuk menguji apakah model regresi mempunyai distribusi yang normal atau tidak. Untuk mengetahui apakah model regresi tersebut normal, digunakan normal P-Plot of Regresion. Apabila dalam diagram tersebut titik-titik menyebar mengikuti garis lurus diagonal, maka model regresi tersebut dapat dikatakan normal. Untuk mengatahui gejala normalitas dapat dilihat pada grafik berikut ini: 


\section{Buletin Ekonomi}

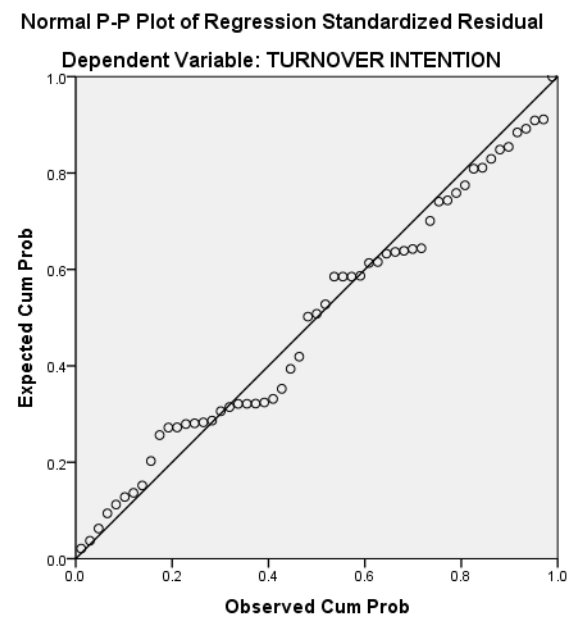

Gambar 3. Uji Normalitas Data

Output ini menjelaskan bahwa pada gambar P-Plot terlihat titik-titik yang mengikuti dan mendekati garis diagonalnya sehingga dapat disimpulkan bahwa model regresi tersebut memenuhi distribusi normal (data normal). Salah satu cara untuk mendeteksi gejala multikolinearitas adalah dengan melihat nilai tolerance value atau Variance Inflation Faktor $(V I F)$ dengan kriteria keputusan sebagai berikut:

\section{Tabel 3.}

Variance Inflation Factor(VIF)

\section{Coefficients $^{\mathrm{a}}$}

\begin{tabular}{lcc}
\hline \multicolumn{3}{c}{ Collinearity Statistics } \\
Model & Tolerance & VIF \\
\hline (Constant) & & 1.987 \\
KEPUASAN KERJA & .503 & 2.070 \\
JOB INSECURITY & .483 & 2.645 \\
LINGKUNGAN & .378 & \\
KERJA & & 2.582 \\
KOMITMEN & .387 & \\
ORGANISASI &
\end{tabular}

Berdasarkan hasil pengujian di atas diketahui bahwa nilai VIF variabel Job Insecurity (2,070), Kepuasan Kerja (1,987), Lingkungan Kerja (2,645), Komitmen Organisasi $(2,582)$. Karena nilai VIF untuk semua variabel kurang dari 10 maka dapat disimpulkan bahwa tidak terjadi gangguan multikolinearitas atau dengan kata lain model regresi ini terbebas dari gejala multikolinearitas

Salah satu cara mendeteksi ada tidaknya heteroskedastisitas adalah dengan melihat grafik Scatter Plot. Syarat menggunakan scatter plot ini yakni: 


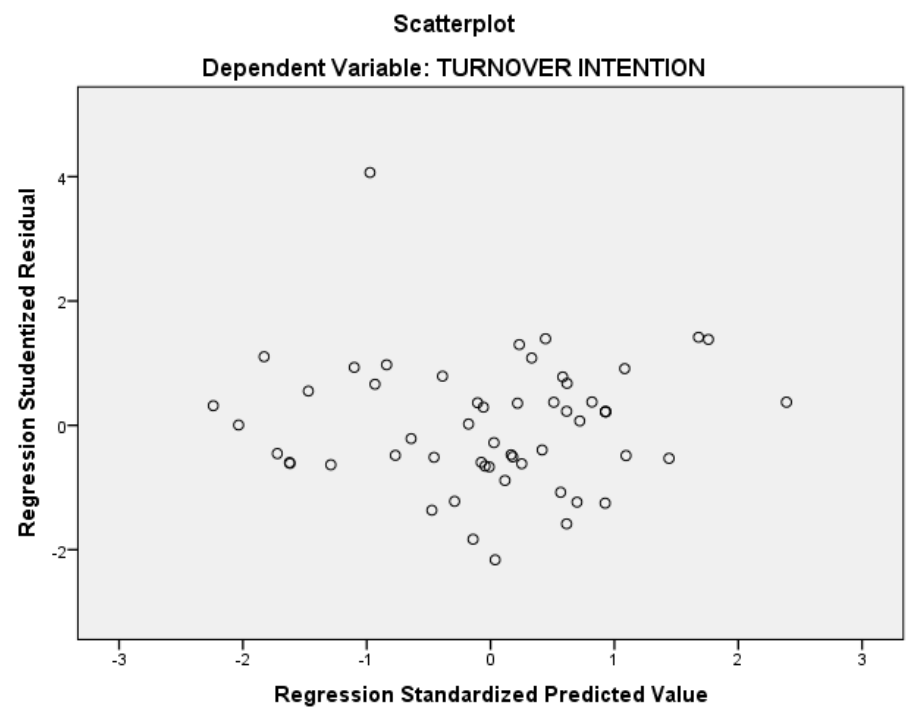

Gambar 4. Hasil Uji Heterokedastisitas

Berdasarkan output di atas diketahui bahwa titik-titik data penyebar di atas dan di bawah atau di sekitar angka 0, titik-titik tidak mengumpul hanya di atas atau di bawah saja, penyebaran titik-titik data tidak membentuk pola bergelombang melebar kemudian menyempit dan melebar kembali serta penyebaran titik-titik data tidak berpola. Dengan demikian dapat disimpulkan bahwa tidak terjadi masalah heteroskedastistas, hingga model regresi yang baik dan ideal dapat terpenuhi.

Tabel 4.

Hasil Analisis Regresi Linier Berganda

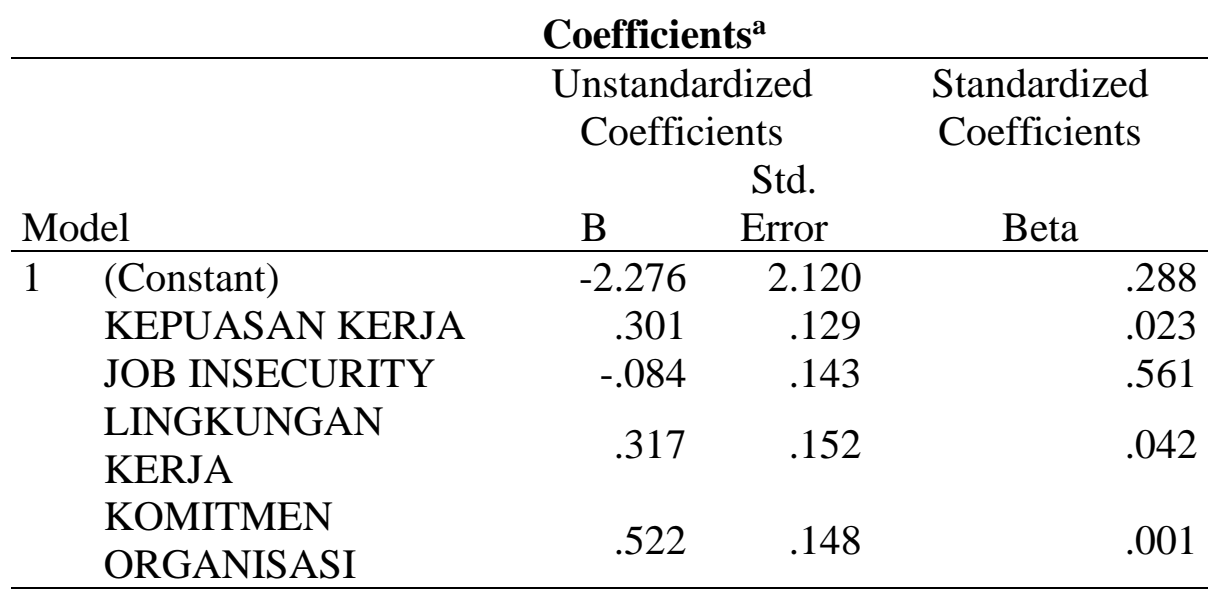

Sumber : Data Primer Diolah | 2018

Dari hasil pengujian analisis regresi berganda seperti yang tertera pada Tabel di atas, maka dapat disusun persamaan regresi berganda sebagai berikut:

$$
Y=(-2,276)-0,084 X_{1}+0.301 X_{2}+0,317 X_{3}+0,522 X_{4}+e
$$

Koefisien korelasi menjelaskan adanya hubungan linear dan arah hubungan dua variabel acak. Jika koefisien korelasi bernilai positif, maka kedua variabel mempunyai hubungan yang searah. Jika koefisien korelasi bernilai negatif, maka kedua variabel mempunyai hubungan terbalik. 
Tabel 5.

Hasil Analisis Koefisien Korelasi

\begin{tabular}{llrrr}
\multicolumn{5}{c}{ Model Summary $^{\mathbf{b}}$} \\
\hline Model & R & R Square & $\begin{array}{c}\text { Adjusted R } \\
\text { Square }\end{array}$ & $\begin{array}{l}\text { Std. Error of } \\
\text { the Estimate }\end{array}$ \\
\hline 1 & $.826^{\mathrm{a}}$ & .682 & .656 & 2.281 \\
\hline
\end{tabular}

Sumber : Data Primer Diolah | 2018

Koefisien korelasi berganda $(\mathrm{R})$ yang diperoleh sebesar 0,826 yang berarti bahwa terdapat hubungan yang sangat erat antara variabel Job Insecurity (X1), Kepuasan Kerja (X2), Lingkungan Kerja (X3), Komitmen Organisasi (X4) terhadap Turnover Intention (Y) karyawan Java Dancer Coffee Malang. Karena hasil R yang sebesar 0,826 atau yang sebesar $82,6 \%$ mendekati $100 \%$. Besarnya sumbangan atau kontribusi semua variabel bebas terhadap variabel terikat dapat dilihat dari besarnya koefisien determinasi $\left(\mathrm{R}^{2}\right)$ yaitu sebesar 0,682 atau 68,2\%. Mampu dijelaskan oleh variabel Job Insecurity (X1), Kepuasan Kerja (X2), Lingkungan Kerja (X3) dan Komitmen Organisasi (X4) terhadap Turnover Intention (Y) dan sisanya sebesar $31,8 \%$ dipengaruhi faktor lain di luar bahan penelitian ini yang terdapat di dalam perusahaan.

\section{Uji Signifikansi Simultan F (Uji F)}

Tabel 6.

Hasil Uji Signifikansi Simultan F (Uji F)

\begin{tabular}{llrrrrr}
\multicolumn{7}{c}{ ANOVA $^{\text {a }}$} \\
\hline Model & $\begin{array}{l}\text { Sum of } \\
\text { Squares }\end{array}$ & Df & \multicolumn{1}{c}{$\begin{array}{c}\text { Mean } \\
\text { Square }\end{array}$} & \multicolumn{1}{c}{ F } & Sig. \\
\hline 1 & Regressio & 557.491 & 4 & 139.373 & 26.780 & $.000^{\text {b }}$ \\
& n & & & & \\
& Residual & 260.218 & 50 & 5.204 & & \\
& Total & 817.709 & 54 & & & \\
\hline
\end{tabular}

Sumber : Data Primer Diolah $\mid 2018$

Hasil uji F menunjukkan F hitung sebesar 26,780 dan F tabel 2,06 dapat dikatakan bahwa pengaruh yang terjadi tersebut signifikan karena $\mathrm{F}$ hitung lebih besar dari $\mathrm{F}$ tabel dengan tingkat signifikan lebih kecil dari $\alpha=5 \%$ atau 0,05 , maka keputusan terhadap Ho ditolak dan Ha diterima. Jadi, hipotesis yang menduga terdapat pengaruh antara Job Insecurity (X1), Kepuasan Kerja (X2), Lingkungan Kerja (X3), Komitmen Organisasi (X4) mempunyai pengaruh yang signifikan terhadap Turnover Intention (Y)karyawan Java Dancer Coffee Malang secara simultan dibuktikan kebenarannya.

\section{Uji Signifikansi Pengaruh Parsial (Uji t)}

Hasil Uji-t menunjukkan bahwa t hitung variabel Job Insecurity (X1), Kepuasan Kerja (X2), Lingkungan Kerja (X3), Komitmen Organisasi (X4) terhadap Turnover Intention (Y) karyawan Java Dancer Coffee Malang. Job Insecurity (X1) sebesar $(-0,585)$ kurang dari t tabel yaitu 1,297 dan tingkat signifikan lebih besar dari $\alpha=5 \%$ atau 0,05 . Kepuasan Kerja (X2) sebesar 2,340 lebih besar dari t tabel yaitu 1,297, Lingkungan Kerja (X3) sebesar 2,086 lebih besar dari t tabel yaitu 1,297, Komitmen Organisasi (X4) sebesar 3,528 lebih besar dari t tabel yaitu 1,297 atau mempunyai tingkat signifikan lebih kecil dari $\square=5 \%$ atau 0,05, maka Ho diterima Job Insecurity tidak mempunyaipengaruh yang signifikan terhadap variabel terikat yaitu Turnover Intention karyawan. Jadi, dapat dijelaskan bahwa Kepuasan Kerja 


\section{Buletin Ekonomi}

(X2), Lingkungan Kerja (X3) dan Komitmen Organisasi (X4) berpengaruh positif dan signifikan terhadap Turnover Intention (Y)karyawan Java Dancer Coffee Malang, sedangkan Job Insecurity (X1) berpengaruh negatif dan tidak signifikan terhadap Turnover Intention (Y) karyawan Java Dancer Coffee Malang.

Tabel 7.

Uji Signifikansi Pengaruh Parsial (Uji t)

Coefficients $^{\mathrm{a}}$

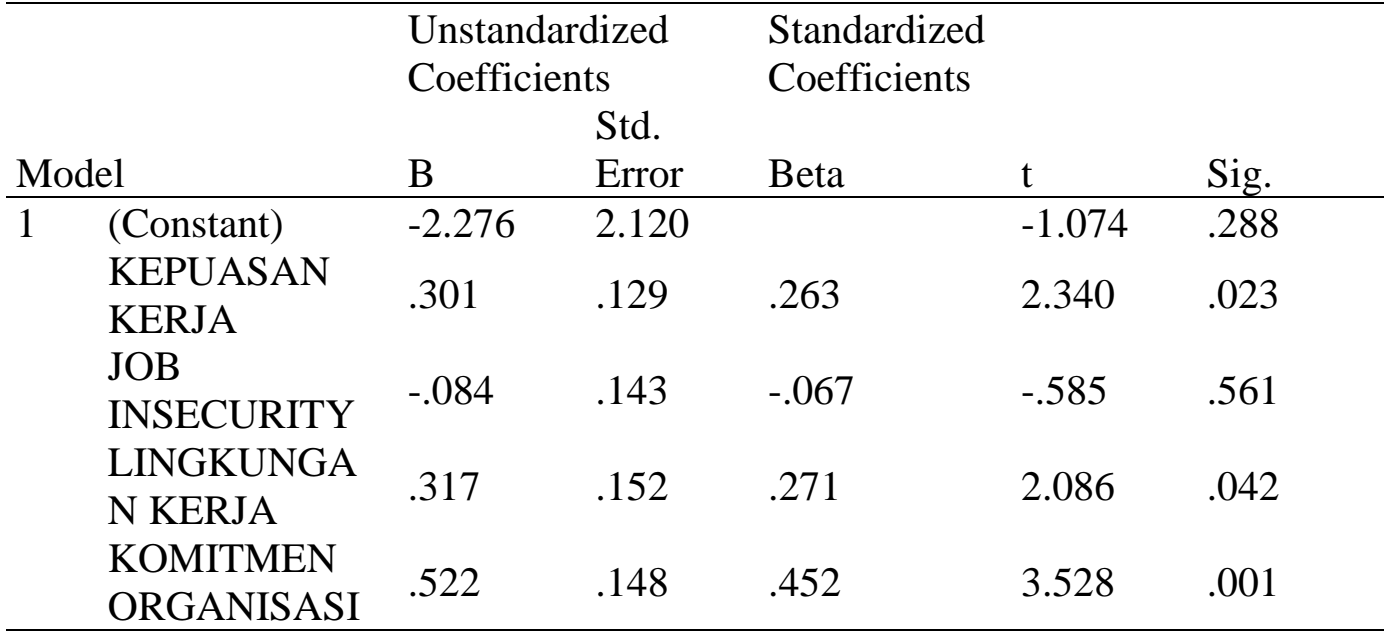

Sumber : Data Primer Diolah | 2018

\section{Pengaruh Job Insecurity terhadap Turnover Intention}

Hasil penelitian menunjukkan bahwa job insecurity berpengaruh negatif terhadap turnover intention terbukti dengan nilai t hitung(-0,585) lebih kecil dari t tabel yaitu 1,297 dan signifikansi sebesar 0,561>0,05 yangberarti bahwajob insecurity tidak berpengaruh terhadap terhadap turnover intention karyawan di Java Dancer Coffee Malang, semakin aman kondisi lingkungan kerja maka akan membuat nyaman dan aman sehingga akan mempengaruhi kecilnya niat karyawan untuk berpindah kerja di Java Dancer Coffee Malang. Dapat diartikan bahwa semakin tinggi rasa tidak aman dalam bekerja maka akan semakin tinggi tingkat turnover intention di perusahaan tersebut. Persepsi karyawan tentang berbagai ancaman terhadap aspek pekerjaan dan keseluruhan pekerjaan mengakibatkan karyawan mengevaluasi kembali hubungannya dengan perusahaan.jika karyawan merasakan suatu tingkat ancaman yang tinggi maka akan semakin tinggi pula keinginan karyawan untuk berpindah kerja.

Untuk memperkecil terjadinya keinginan karyawan untuk berpindah kerja, upaya dari pihak Java Dancer Coffee di antaranya adalah, pihak manajemen harus dapat mempekerjakan karyawan sesuai dengan keahliannya sehingga hal itu akan mempunyai arti khusus bagi karyawan dan hal itu juga akan memperkecil terjadinya kesalahan karyawan.Peran manajemen jga diperlukan dalam rangka memperkecil terjadinya keinginan untuk berpindah karyawan, salah satunya yaitu apabila ada karyawan yang melakukan kesalahan maka sanksi yang diberikan adalah berupa peringatan beberapa kali dan bukan langsung dikeluarkan.Pihak manajemen juga diharapkan untuk tidak mencari-cari kesalahan karyawan semua harus dapat melewati prosedur yang baik dan benar.

\section{Pengaruh Kepuasan Kerja terhadap Turnover Intention}

Hasil penelitian menunjukkan bahwa kepuasan kerja berpengaruh positif terhadap turnover intention terbukti dengan nilai t hitung 2,340 lebih besar dari t tabel yaitu 1,297 dan signifikansi sebesar $0,023<0,05$ dapat diartikan bahwa semakin tinggi tingkat kepuasan kerja karyawan maka keinginan berpindah kerja (turnover intention) karyawan pada Java Dancer 


\section{Buletin Ekonomi}

Coffee akan semakin kecil. Oleh karena itu pihak manajemen perusahaan diharapkan dapat menyikapi dengan baik kebijakan yang dikeluarkan, seperti sikap adil dari pemimpin dalam memberikan perhatian, dukungan pemimpin terhadap bawahannya maupun keadilan dalam memberikan kesempatan yang sama kepada karyawan.

Kepuasan dan ketidakpuasan karyawan dapat berdampak pada pada produktivitas, kemangkiran dan keluarnya karyawan (Robbins, 2003). Karyawan yang lebih puas kemungkinan besar lebih lama bertahan dengan perusahaan, begitu pula sebaliknya karyawan yang tidak puas akan cenderung untuk keluar dari pekerjaannya, mereka mencari sesuatu yang lebih baik di tempat lain dan meninggalkan perusahaan walaupun rekan kerja mereka merasa lebih puas dan memilih untuk tetap tinggal di sana. Jadi, keluarnya karyawan cukup merugikan perusahaan baik secara langsung maupun tidak langsung, karena dapat mempengaruhi karyawan lainnya yang masih tetap bekerja disana, mereka akan merasa tidak puas harus berpisah dengan rekan kerjanya yang bernilai dan timbul gangguan pola sosial yang telah dibina selama ini. Di samping itu untuk dipertimbangkan kemungkinan yang timbul dari keadaan tersebut yaitu keterbukaan kesempatan yang lebih besar untuk melakukan promosi intern dan tambahan keahlian pegawai yang baru diangkat.

\section{Pengaruh Lingkungan Kerja terhdap Turnover Intention}

Hasil penelitian menunjukkan bahwa lingkungan kerja berpengaruh potif terhadap turnover intention terbukti dengan nilai t hitung 2,086 lebih besar dari t tabel yaitu 1,297 dan signifikansi sebesar 0,042<0,05 yang berarti bahwa jika variabel ligkungan kerja mengalami kenaikan, maka tingkatturnover intention akan menurun. Dengan kata lain semakin kondusif suasana lingkungan kerja, maka tingkat keinginan untuk berpindah semakin kecil. Hal ini sependapat dengan apa yang dikemukakan Hal Siagian (2008) bahwa lingkungan kerja berdampak besar dalam mempengaruhi keinginan karyawan untuk pindah tempat.

Dengan terbuktinya penelitian tersebut, maka upaya yang dilakukan oleh pihak manajemen Java Dancer Coffee Malang adalah konsisten terhadap peraturan yang telah ditetapkan. Seringnya perubahan terhadap peraturan dalam menerapkan kebijakan sering membuat karyawan bingung sehingga mempengaruhi ketidakpuasan karyawan dalam bekerja, hal ini lah yang akan mempengaruhi keinginan karyawan untuk pindah kerja.

Pengaruh Komitmen Organisasi terhadap Turnover Intention

Penelitian menunjukkan bahwa komitmen organisasi berpengaruh positif terhadap turnover intention terbukti dengan nilai t hitung 3,528 lebih besar dari t tabel yaitu 1,297 dan signifikansi sebesar $0,001<0,05$ yang berarti bahwa jika rasa komitmen organisasimengalami kenaikan, maka tingkat turnover intention akan menurun. Di dalam tingkatan yang paling umum, komitmen organisasi dapat diartikan sebagai tingkatan saat seorang karyawan telah berdedikasi kepada organisasinya dan kesanggupan untuk bekerja atas kepentingan organisasi tersebut, serta kecenderungan untuk tetap menjadi anggota organisasi tersebut, seperti yang dikemukakan oleh Robbins dan Judge (2007), komitmen sebagai suatu keadaan dimana seorang individu memihak organisasi serta tujuan-tujuan dan keinginannya untuk mempertahankan keangotaannya dalam organisasi. Hal ini sangat berdampak baik bagi perusahaan jika mampu mempertahankan karyawannya karena perusahaan tidak perlumengeluarkan biaya untuk mencari karyawanyang baru.

\section{KESIMPULAN DAN SARAN \\ Kesimpulan}

Tujuan penelitian ini yaitu menguji pengaruh job insecurity, kepuasan kerja, lingkungan kerja dan komitmen organisasi terhadap turnover intention karyawan secara simultan dan parsial. Sampel yang digunakan dalam penelitian ini berjumlah 55 orang 


\section{Buletin Ekonomi}

karyawan Java Dancer Coffee Malang, Pernyataan dari variabel Job Insecurity (X1), Kepuasan Kerja (X2), Lingkungan Kerja (X3), Komitmen Organisasi (X4) dan Turnover Intention (Y) mempunyai koefisien Alpha lebih dari 0,7. Dengan demikian berarti bahwa item pertanyaan untuk semua variabel tersebut dinyatakan reliabel.

Hasil dari uji asumsi klasik yang diteliti menunjukkan bahwa pada uji multikolineritas menunjukkan bahwa nilai VIF variabel bebas lebih kecil dari angka 10. Sehingga pada analisis ini tidak terjadi gejala multikolineritas. Dengan kata lain, variabel bebas menjelaskan pengaruhyang berbeda terhadap variabilitas variabel terikat. Lalu, pada uji heterokedastisitas tidak terlihat bahwa terdapat pola yang jelas, karena titik-titik menyebar di atas dan di bawah angka 0 pada sumbu Y, sehingga dapat dikatakan bahwa pada model proporsi ini tidak terjadi gejalah Heterokedastisitas. Dan pada uji hasil normalitas, output ini menjelaskan bahwa pada gambar P-Plot terlihat titik-titik yang mengikuti dan mendekati garis diagonalnya sehingga dapat disimpulkan bahwa model regresi tersebut memenuhi distribusi normal (data normal). Jadi, dapat disimpulkan bahwa distribusi data tersebut berdistribusi normal.

Hasil uji koefisien determinasi $\left(\mathrm{R}^{2}\right)$ sebesar 0,682 atau 68,2\% Turnover Intention (Y) karyawan Java Dancer Coffee dipengaruhi oleh Job Insecurity (X1), Kepuasan Kerja (X2), Lingkungan Kerja (X3) dan Komitmen Organisasi (X4) dan sisanya sebesar 31,8\% dipengaruhi faktor lain di luar bahan penelitian ini yang terdapat di dalam perusahaan. Hasil uji $\mathrm{F}$ menunjukkan $\mathrm{F}$ hitung sebesar 26,780 dan $\mathrm{F}$ tabel 2,06 dapat dikatakan bahwa pengaruh yang terjadi tersebut signifikan karena $\mathrm{F}$ hitung lebih besar dari $\mathrm{F}$ tabel dengan tingkat signifikan lebih kecil dari $\alpha=5 \%$, maka keputusan terhadap Ho ditolak dan Ha diterima. Jadi, hipotesis yang menduga terdapat pengaruh antara Job Insecurity (X1), Kepuasan Kerja (X2), Lingkungan Kerja (X3), Komitmen Organisasi (X4) mempunyai pengaruh yang signifikan terhadap Turnover Intention (Y) karyawan Java Dancer Coffee Malang secara simultan dibuktikan kebenarannya. Hasil Uji-t menunjukkan bahwa $\mathrm{t}$ hitung variabel Kepuasan Kerja (X2) sebesar 2,340, Lingkungan Kerja (X3) sebesar 2,086 dan Komitmen Organisasi (X4) sebesar 3,528 lebih besar dari t tabel yaitu 1,297. Sedangkan variabel Job Insecurity (X1) sebesar (-0,585) kurang dari t tabel yaitu 1,297 atau mempunyai tingkat signifikan lebih kecil dari $\square \square=5 \%$.Jadi, dapat dijelaskan bahwa Kepuasan Kerja (X2), Lingkungan Kerja (X3) dan Komitmen Organisasi (X4) berpengaruh positif dan signifikan terhadap Turnover Intention (Y) karyawan Java Dancer Coffee Malang, Sedangkan Sedangkan Job Insecurity (X1) tidak mempunyaipengaruh yang signifikan terhadap variabel Turnover Intention (Y). karyawan Java Dancer Coffee Malang. Variabel Komitmen Organisasi paling berpengaruh terhadap Turnover Intention dibandingkan variabel lain. Hal ini dapat diketahui berdasarkan hasil perhitungan koefisien regresi (b) sebesar 0,522.

Saran

Saran yang dapat diberikan antara lain: (1) Ada baiknya jika kebijakan yang akan diterapkan pada perusahaan dipertimbangkan dengan matang, sehingga tidak terjadi perubahan aturan yang terjadi terus menerus, jadi karyawan tidak merasa bingung menjalankan tugas yang ada sebab aturan yang diberikan telah jelas dan terstruktur. Hendaknya perusahaan memperhatikan kapasitas karyawannya sehingga mampu menentukan target yang tepat dan mampu dicapai karyawan melalui pekerjaan yang maksimal. Pembebanan target yang diberikan harus dapat diimbangi dengan reward yang sepadan; (2) Untuk meningkatkan kepuasan kerja karyawan ada baiknya pihak manajemen Java Dancer Coffee senantiasa mengoptimalkan rapat atau briefing yang dilaksanakan pada tiap bagian atau divisi, 


\section{Buletin Ekonomi}

\section{DAFTAR PUSTAKA}

Bintari, Seltika. 2012. Analisis Pengaruh Lingkungan Kerja, Kepuasan Kerja dan Job Insecurity terhadap Keinginan Berpindah Kerja. Jurnal Bisnis Univesitas Brawijaya. Malang.

Fitriany, dkk. 2010. Pengaruh Job Insecurity terhadap Kepuasan dan Turnover Intention. Jurnal Kajian Bisnis, Vol. 56.

Ghozali, Imam.2006. Aplikasi Analisis Mulivariative dengan Program SPSS. Semarang.

Halimah, Tika, dkk. 2016. Pengaruh Job Insecurity, Kepuasan Kerja dan Lingkunagn Kerja terhdapa Turnover Intention Pramuniaga di Galael Supermarket (Studi Kasus pada Galael Superindo Kota Semarang). Semarang.

Hellgren, J., M. Sverke, dan K. Isaksson. 1999. "A Two-Dimensional Approach to Job insecurity: Consequences For Employee Attitudes and Well-being", European Journal of Work and Organizational Psychology, 8 (2): 179-195.

Irvianti dan Verina. 2015. Analisis Pengaruh Stres Kerja, Beban Kerja dan Lingkungan Kerja terhadap Turnover Intention Karyawan pada PT XL AXIATA Tbk Jakarta. Jurnal Bisnis BINUS University, Vol. 6. Jakarta.

Koestanto dan Rudi. 2017. Pengaruh Job Insecurity, Lingkungan Kerja dan Kepuasan Kerja terhadap Keinginan Berpindah Kerja Karyawan Hotel Grand Candi Semarang. Jurnal Ilmiah Pariwisata, Vol. 13. Semarang.

Pramudika, Christian, dkk. 2017. Pengaruh Kepuasan Kerja, Pengembangan Karir dan Komitmen Organisasi terhadap Turnover Intention (Studi Empiris pada Karyawan Belle View Hotel Semarang). Jurnal Manajemen, Vol. 3. Skripsi Program Sarjana Manajemen Universitas Pandanaran. Semarang.

Robbins, Stephen P. 2006. Perilaku Organisasi. Prehallindo. Jakarta.

Wicaksono, Windu. 2016. Pengaruh Job Isecurity, Job Stress dan Work-Family Conflict terhdapa Turnover Intention CV. Batik Indah Rara Djonggrang. Jurnal Ekonomi dan Bisnis Universitas Muhammadiyah Yogyakarta. Yogyakarta.

Writasari, L.2009. Anlasis Pengaruh Kepuasan Kerja dan Komitmen Organisasional terhadap Turnover Intention Studi Empiris pada Novotel Semarang. Tesis Program Pasca Sarjana Magister Manajemen Universitas Diponegoro. Semarang. 